Article

\title{
A Framework for Assessing Democratic Qualities in Collaborative Economy Platforms: Analysis of 10 Cases in Barcelona
}

\author{
Mayo Fuster Morell ${ }^{1}$ and Ricard Espelt ${ }^{2, *}$ (iD \\ 1 Berkman Klein Center for Internet and Society, Harvard University, Cambridge, MA 02138, USA; \\ mayo.fuster@eui.eu \\ 2 Internet Interdisciplinary Institute, Open University of Catalonia, 08289 Barcelona, Spain \\ * Correspondence: ricardespelt@uoc.edu; Tel.: +34-667-515-503
}

Received: 2 June 2018; Accepted: 21 July 2018; Published: 25 July 2018

\begin{abstract}
The term "collaborative economy" or "collaborative economy platforms" refers to exchange, sharing, and collaboration in the consumption and production of capital and labor among distributed groups, supported by a digital platform. Collaborative economies' use is growing rapidly and exponentially, creating high expectations of sustainability and their potential to contribute to the democratization of the economy. However, collaborative economy platforms lack a holistic framework to assess their sustainability and pro-democratization qualities. In addition, there is confusion about platforms which present themselves as collaborative when they actually are not, and similar uncertainties and ambiguities are associated with diverse models. To address this confusion, this article provides a framework for assessing the pro-democratic qualities of collaborative economy initiatives. It was applied to 10 cases in the context of the city of Barcelona. The methods used in this study include mapping and typifying 10 collaborative economy cases in the city, structured and in-depth interviews, and a co-creation session. The results indicate the presence of several modalities for favoring democratic values in a collaborative economy.
\end{abstract}

Keywords: collaborative economy; platform cooperativism; democratic quality

\section{Introduction}

The term "collaborative economy" or "collaborative economy platforms" refers to exchange, sharing, and collaboration in the consumption and production of capital and labor among distributed groups, supported by a digital platform. The use of collaborative economies is growing rapidly and exponentially, bringing high expectations of sustainability for its potential to contribute to the democratization of the economy. However, collaborative economy platforms lack a holistic framework for assessing these sustainability and pro-democratization qualities. In addition, there is confusion about platforms that present themselves as collaborative when they actually are not, and similar uncertainties and ambiguities are associated with diverse models [1].

The disruptive impact of the best-known economy platform model, that of extractionist "unicorn" corporation (a privately held startup company valued at over $\$ 1$ billion) platforms such as Uber and Airbnb, has provoked huge controversy [2]. Successful "alternative" and truly collaborative models exist, such as open commons, platform cooperativism, and decentralized organizations based on social economy and open knowledge, but these have received limited research attention.

First, this article reviews collaborative economy conceptualization and previous attempts to classify collaborative economies to provide a framework of pro-democratic qualities. Then, we apply the resulting methodology in 10 relevant cases located in the city of Barcelona. At that time, we show the results and, finally, present the conclusions and discussion. 


\subsection{Collaborative Economy}

The term collaborative economy or collaborative platforms economy (which can only be considered collaborative and commons-oriented under a particular set of conditions) refers to the exchange (matching supply and demand), sharing and collaborating in the consumption, and production of capital and labor among distributed groups supported by a digital platform [3]. It is growing rapidly and exponentially, and has become a top priority for governments around the globe (i.e., European Commission, 2016 [4]). However, the collaborative economy suffers from important challenges. We would like to highlight and address two of them: (1) The platform collaborative economy is creating high sustainability expectations for its potential to contribute to a sustainable development of society [5-9], and for its potential to contribute to the democratization of economy [10]. However, the platform collaborative economy lacks a holistic framework to assess these sustainability and pro-democratization qualities. Furthermore, the sustainable design of platform has considered questions of technological and economic aspects, but has not integrated other sustainability relevant questions, such as the environmental impact, gender and inclusion, or its policy implications, lacking a proper multidisciplinary perspective of the platform economy; (2) There is a confusion about the platforms which present themselves as collaborative while actually they are not, and similar uncertainties and ambiguities are associated with diverse models. The disruptive impact of the best known platform economy model, that of Unicorn extractionist corporation platforms such as Uber and Airbnb, is provoking huge controversy [2]. Successful "alternative" and truly collaborative models exist, such as open commons, platform cooperativism and decentralized organizations based on a social economy and open knowledge, with examples such as Fairmondo. Nonetheless, these have received neither policy nor research attention. Additionally, there is a lack of a classification system that helps to establish the difference.

\subsection{Previous Attempts to Classify Models of Collaborative Economy}

There have been previous attempts to classify collaborative economies. The Spanish Association of the Digital Economy (Adigital) carried out a study, "Collaborative models are on demand in digital platforms" [11], to distinguish among the activities of: (1) Collaborative Economy: a digital platform serving as an intermediary between equals, either between organizations or individuals, with or without economic consideration; (2) Economy on Demand: a digital platform serving as an intermediary between a professional and a user; and (3) Service Economy: a digital platform that, without disintermediation, connects users with goods for their temporary use, adapting to the effective use time required by users and making the spatial location more flexible.

If we focus on the first group, we see that it includes projects with such highly disparate approaches as AirBnB (a vacation rental platform owned by a multinational) and Goteo (a crowdfunding platform based on commons principles owned by a foundation). In fact, the interface or platform design both conditions and predefines the social relations-related, for example, to interaction mechanisms, regulation, profile information, or promotion-among users [12,13].

Netnographic investigation of 55 collaborative consumption platforms in The Triple Impact Assessment of P2P Collaborative Consumption in Europe project [14] defined three types of collaborative consumption platforms: (1) Network Oriented Platforms (e.g., Airbnb, Blablacar, TimeRepublick, or Eatwith), where users have many forms of communication in order to get digital reputation and show confidence to engage other users; (2) Transaction Oriented Platforms (Vibbo or Nolotiro), with fewer communication and interaction tools, focused on convenience and more connected to the traditional consumer and provider roles; and (3) Community Oriented Platforms (WWOPP voluntaries network, La Colmena que dice sí or CiroSel), linked to a social or environmental mission and to a strong code of conduct. These platforms develop some collective rules beyond self-management regulation based on the capacity of the individuals to manage their confidence networks. Gordo et al. [15] determined the relevance of the transformation of the consumer into an entrepreneur or the new role of prosumer. In the end, in some platforms, users provide knowledge, properties, or services while intermediaries are those 
who really earn money [8]. At the same time, netnographic research highlights the necessity to precisely review how each platform initiative works and the platform's social, economic, and environmental impacts $[15,16]$.

In this context, where a critical and holistic review of digital platforms that promote the collaborative economy is required, a new key concept emerges: "platform cooperativism". According to Scholz [17], a digital platform must be based on collective ownership, decent payment and security of income for its workers, the transparency and portability of the data created, appreciation and recognition of the value generated by the platform's activity, collective decision-making, a protective legal framework, transferable protection of workers and the coverage of social benefits, protection against arbitrary conduct in the rating system, rejection of excessive supervision in the workplace, and, finally, the right of the workers to disconnect. As stated by Scholz, on the one hand, the platforms must be shaped around the values of cooperativism. On the other hand, digital tools must amplify the scalability and the social and economic impact of cooperative organizations. At the same time, Fuster Morell [10] indicated that the very construction of technology platforms is not a minor issue, and that cooperative platforms should adopt open software and licenses. In short, creating a self-managed governance that allows the articulation of community development around the digital commons [18] has to be approached as "open cooperativism" [19], an antithesis of the unicorn and corporate platforms.

There have been previous attempts to establish delimitations in collaborative production or commons-based peer production (CBPP) [20]. This is the case of the four freedoms of free software. The four freedoms are used in relation to whether a particular software program qualifies as "free" software. A program is free software if it adequately gives users all four freedoms. Although the four freedoms for software might resemble what we are trying to do here, $C B$ relates to a collective process and delimitation criteria for the features of that process. By contrast, the definition of free software is individualistically driven and built based on individual freedoms, not the features of the process as a whole.

From our point of view, it is necessary to consider the complexity of the classification of collaborative economy platforms, and specific analyses are required to distinguish models. For example, during the last three years, a new type of agrofood consumer platform was spreading its activity in Barcelona: La Colmena que dice sí. Despite using an approach similar to that of cooperatives to engage potential members (disintermediation between local producers and consumers), the organization's values were far from the values of social and economic solidarity [21]. Departing from this reflection, in this paper, we provide a framework to characterize models of collaborative economy and visualize their qualities.

In this article, we propose a framework for the democratic qualities of collaborative economy platforms. The framework considers the dimensions of governance design, economical strategy, technological base, knowledge policies, and social responsibility regarding externalization impact of the platforms. The democratic balance is an analytical tool that helps to visualize the democratic qualities of collaborative economy initiatives, differentiate models, provide insight into the sustainability of their design, and inform technological development (see Figure 1). 


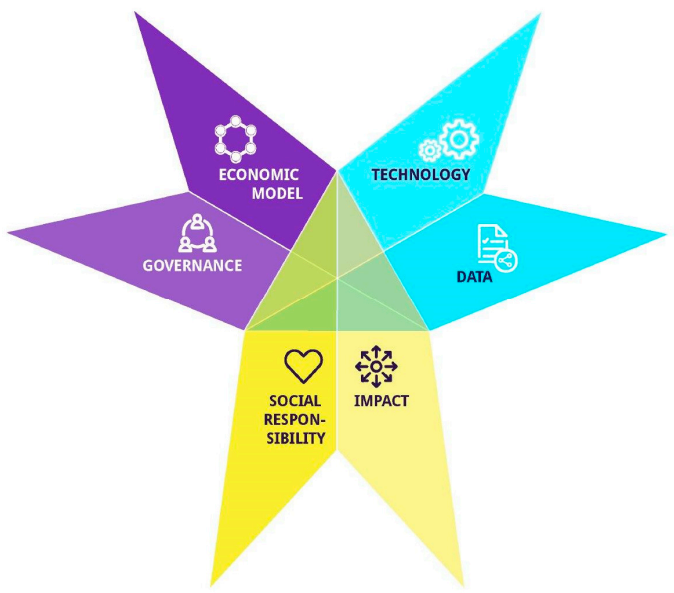

Figure 1. Procommons collaborative economy analytical star framework.

\subsection{A Framework of Democratic Qualities of Collaborative Economy Platforms}

The democratic qualities of the collaborative economy are articulated around three main dimensions, with in six subdivisions:

1. Governance and Economic: We believe that these two sub-dimensions are interconnected. Thus, the way that the project or platform is governed is connected to the underlying economic model.

1.a. Governance: This aspect regards democratic enterprises and involving the community generated value in the platform governance. This aspect also regards the decision-making model of the organization, and mechanisms and political rules of participation in the digital platform.

1.b. Economic model: This aspect regards whether the project's financing model is based on private capital, ethical finance, or a distributed fund (crowdfunding or match-funding), the business models, mechanisms of economic transparency, how far profitability is driven in the whole plan, distribution of value generated, and equity payment and labor rights. This aspect regards ensuring equitable and timely remuneration, and access to benefits and rights for workers (maximization of income, salary predictability, safe income, protection against arbitrary actions, rejection of excessive vigilance at the workplace, and the right to disconnect).

2. Knowledge and Technological policies: In the same sense, knowledge and technological policies are interconnected. Thus, the adoption of certain technological tools or licenses is going to impact the way the platform promotes knowledge.

2.a. Knowledge policy: Regards the property type, as established by the license used (free licenses or proprietary licenses) for the content and knowledge generated, type of data (open or not), the ability to download data (and in which formats), and the promotion of the transparency of algorithms, programs, and data. This aspect regards privacy awareness, the protection of property including personal data, and preventing abuse and the collection or sharing of data without consent. This aspect also regards guaranteeing the portability of data and reputation.

2.b. Technological policy: This aspect regards the mode of property and freedom associated with type of software used and its license (free or proprietary) and the model of technology architecture: distributed (using blockchain, for example) or centralized (software as a service).

3. Social responsibility and impact. These dimensions relate to any source of awareness and responsibility regarding the externalities and negative impacts, such as social exclusion and social inequalities, the inclusion of gender, regarding the equal access to the platform of people with all kinds of income and circumstances in an equitable and impartial way (without discrimination). This aspect regards compliance with health and safety standards that protect the public, and the environmental impact (promoting sustainable practices that reduce emissions and waste, taking into account the rebound effect they can generate and the most efficient use of resources, the origin and production 
conditions of the goods and services they offer, minimizing resource use, and recycling capacity), and the impact in the policy arena, and the preservation of the right to the city of its inhabitants and the common good of the city. This aspect also regards the protection of the general interest, public space, and basic human rights such as access to housing.

\section{Materials and Methods}

The methodology, aimed at testing the application of the above six democratic qualities, was based on an in-depth 10 case study comparison. Data collection was based on digital ethnography (to collect indicators for the cases and get familiar with them), co-creation sessions with the cases, and an interview with each of the cases. Data were collected in May 2017. Data analysis combined qualitative and visual analysis of data from co-creation sessions and interviews.

\subsection{Sample}

The empirical work departs from a previous mapping of 1000 cases of Collaborative Economy in Barcelona, based on the P2P Value directory on collaborative economy. From these resources, we selected 10 based on the following criteria:

1. Projects with activity in Barcelona.

2. Projects based on collaborative production.

3. Projects with a significant level of activity, rather than in a very preliminary stage.

4. Projects with a social orientation, meaning closer to the cooperative platform than to the unicorn platform scope.

5. We selected the cases to ensure diversity, and based on being significantly relevant.

The cases are El Recetario, SmartIB, Goteo, Katuma, Bdtonline, XOBB, FreeSound, Sentilo, eReuse, and Pam a Pam. A description of each is provided in Section 3.

\subsection{Indicators Criteria}

For each dimension, we assessed two variables with three grades of accomplishment.

\subsection{Analytical Methods}

We performed a previous web observation to collect more information about the selected platforms, a co-creation session (5 May 2017), and an interview of the 10 cases, following the case study methodology [22]. Departing from our 10 cases chosen, we designed a co-creation session divided into three steps with three main objectives. In the first part, the participants indicated their evolution in the form of a graph, highlighted milestones, and projected their future evolution. In the second part, each platform actively shared how their approach to each point of the commons star diagram (Figure 1: economic model, social responsibility, knowledge and technological policy, and governance model). Finally, all participants identified the challenges of a collaborative procommon economy in terms of specific needs of the sector, technological demands, and public policy recommendations.

\section{Results: Analytical Framework for the Democratic Qualities of 10 Cases of Collaborative Economy in Barcelona}

In this section, we present the analytical framework of the democratic qualities of collaborative economy (Figure 1) applied to 10 cases that we analyzed based on each collaborative economy's performance of the star of commons qualities (El Recetario, SMart IB, Goteo, Katuma, Bdtonline, FreeSound, XOBB, eReuse, Sentilo, and Pam a Pam). See Table 1 for a comparison of the cases on their performance of each of the qualities. 
Table 1. Indicators of procommons collaborative economy assessment.

\begin{tabular}{|c|c|c|c|c|}
\hline Dimension & Indicator & Fulfillment & Partial Fulfillment & Unfulfillment \\
\hline \multirow[t]{2}{*}{ GOV } & $\begin{array}{c}\text { Type of } \\
\text { organization }\end{array}$ & $\begin{array}{l}\text { Procommon organization } \\
\text { (public administration) }\end{array}$ & $\begin{array}{l}\text { Democratic type of } \\
\text { governance (foundation, } \\
\text { association, cooperative) }\end{array}$ & Private company \\
\hline & Open participation & $\begin{array}{l}\text { Governance is based on } \\
\text { open participation }\end{array}$ & $\begin{array}{l}\text { Some participation tools are } \\
\text { provided }\end{array}$ & $\begin{array}{l}\text { No participation } \\
\text { tools are provided }\end{array}$ \\
\hline \multirow{2}{*}{ ECON } & Goal & Non-profit & Middle profit & Profit \\
\hline & Transparency & $\begin{array}{l}\text { Any member of organization } \\
\text { can access to the economic } \\
\text { information }\end{array}$ & $\begin{array}{l}\text { Some economic information } \\
\text { is accessible to the } \\
\text { community }\end{array}$ & $\begin{array}{l}\text { No economic } \\
\text { information is } \\
\text { provided }\end{array}$ \\
\hline \multirow[t]{2}{*}{$\mathrm{TECH}$} & $\begin{array}{c}\text { Free and } \\
\text { open-source } \\
\text { software (FOSS) }\end{array}$ & $\begin{array}{l}\text { All tech tools are based on } \\
\text { FOSS }\end{array}$ & $\begin{array}{c}\text { Some of tech tools are based } \\
\text { on FOSS }\end{array}$ & $\begin{array}{l}\text { No tech tool is } \\
\text { based on FOSS }\end{array}$ \\
\hline & Decentralized & $\begin{array}{c}\text { Tech architecture is fully } \\
\text { decentralized }\end{array}$ & $\begin{array}{c}\text { Tech architecture is partially } \\
\text { decentralized }\end{array}$ & $\begin{array}{c}\text { Tech architecture is } \\
\text { centralized }\end{array}$ \\
\hline \multirow[t]{2}{*}{ KNOWL } & Copyleft & Content licenses are copyleft & $\begin{array}{l}\text { Part of the contents are open } \\
\text { access }\end{array}$ & $\begin{array}{l}\text { All rights of } \\
\text { contents are } \\
\text { reserved }\end{array}$ \\
\hline & Open data & All data are downloadable & Some data are downloadable & $\begin{array}{c}\text { No data are } \\
\text { downloadable }\end{array}$ \\
\hline \multirow[t]{2}{*}{ SOC } & Inclusion & $\begin{array}{c}\text { Project has a relevant role in } \\
\text { inclusion }\end{array}$ & $\begin{array}{l}\text { Project has some inclusion } \\
\text { policies }\end{array}$ & $\begin{array}{l}\text { No policy or action } \\
\text { about inclusion }\end{array}$ \\
\hline & Green & $\begin{array}{c}\text { Project has a relevant role in } \\
\text { environment }\end{array}$ & $\begin{array}{l}\text { Project has some } \\
\text { environment policies }\end{array}$ & $\begin{array}{l}\text { No policy or action } \\
\text { about environment }\end{array}$ \\
\hline
\end{tabular}

\subsection{The Democratic Qualities of 10 Cases of Collaborative Economies in Barcelona}

Analysis of the cases regarding the commons balance follows.

\subsubsection{El Recetario}

A collaborative platform, created in 2007, focused on research, experimentation, and reuse of waste for the construction of furniture and accessories, where the community of creators (700) share what they do and how they do it (through recipes, 450), learning from it and collaborating with others.

- Governance: Voluntary open participation.

- Economic model: Participated in a Universidad Internacional de Andalucia (UNIA) match-funding Goteo campaign (2015), which allows them to improve the project. However, a sustainable economic model is not yet defined.

- Technological policy: The technological platform is developed in Wordpress and, despite being planned, the whole platform code is not yet open.

- Knowledge policy: At the same time, the content is under a Creative Commons license (BY-SA. 4.0 copyleft license).

- Social responsibility: El Recetario is in the transition of becoming a consumer/producer cooperative platform.

\subsubsection{SMart IB}

SMart is an abbreviation for the French phrase, "Societé Mutuelle pour Artististes". SMart is a non-profit organization that was launched in Belgium in 1994 under the name of SMartBe. Through the ESempleo Program, founded by European sources and managed by CEPES Andalucía, SMartBe came into contact in 2011 with a cooperative business group from Andalucía that brought together the social cooperatives AURA ETT, ACTÚA SERVICIOS, and A2A Formación, among others. Finally, the new Law 14/2011 of Andalusian Cooperative Societies introduced advanced societal models of social 
innovation, creating a legal environment in which SMart Ibérica could begin to operate in Spain in May 2013. Currently, the Spanish cooperative receives the economic support of the Belgian cooperative. The project has expanded well, with 3000 members in Spain and 800 in Catalonia.

- Governance: A governing board makes the decisions of the cooperative, and the users are invited once or twice a year to hold an assembly.

- Governance: Voluntary open participation.

- Economic model: Each member pays a $150 €$ initial share capital contribution and 7.5\% services commission. With this capital, the organization pays members' bills in advance.

- Technological policy: There is no technological platform running yet.

- Knowledge policy: The knowledge generated is not open.

- Social responsibility: The project promotes cultural and artistic activity.

\subsubsection{Goteo}

Goteo is a crowd/match-funding platform constituted as a foundation. The project started through a collaborative founding investigation in 2010, and the first version of the platform launched in 2011. Currently, Goteo has more than 90,000 users, raising 4 million Euros.

- Governance: As a foundation, the decision-making process is carried by a small group of people.

- $\quad$ Economic model: Users pay a $4 \%$ commission, but the promoters intend to arrive at $0 \%$.

- Technological policy: Software is subject to a copyleft license (AGPL).

- Knowledge policy: Some platform data are freely downloadable.

- Social responsibility: In terms of social impact, all projects which participate in campaigns must define the social responsibility of their actions.

\subsubsection{Katuma}

Katuma is an Agro-food consumption platform based on commons collaborative economy values. The project was launched in 2017 and was developed by Coopdevs, a non-profit association focused on free and open software to promote social and solidarity economy projects.

- Governance: A membership cooperative governance is planned.

- Economic model: The intention is to found the platform with membership fees.

- Technological policy: The platform is developed with open software.

- Knowledge policy: The contents are under a Creative Commons (BY NC) license.

- Social responsibility: The project focuses on connecting producers and consumers in terms of social justice.

\subsubsection{Bdtonline}

Bdtonline is a platform of a time banking association, Associació pel Desenvolupament dels Bancs del Temps (ADBdT), which uses TimeOverFlow software, also created by Coopdevs. The association and software were developed and raised in 2012. Currently, 47 organizations use this platform with 5800 users. One of the main goals of the organization is its usability independently of the characterization of the organization.

- Governance: Annual assembly, they use Loomio groups as a framework of members' participation.

- Economic model: All economic information is published on the website. The project is supported by membership fees and a small number of monthly voluntary donations, which are not enough to invest in improving the project, this being just the developer's task.

- Technological policy: Public domain license.

- Knowledge policy: Wiki space under public domain license.

- Social responsibility: Large number of organizations and users. 


\subsubsection{FreeSound}

The project, started in 2005, is promoted by Pompeu Fabra University and has a research group with the objective of gathering free content for educational purposes and research. It was a success, winning prizes from the City Council (2005) and Google (2009). Currently, the platform, which is hosted in a central server, has more than six million registered users and over 400,000 registered sounds.

- Governance: Open forum participation moderated by research members.

- Economic model: Growth has been deliberately slow to avoid any financial problems, which could force it to close. The majority of limited economic sources are from research. Promoters are studying new ways of funding based on different types of users or a Wikimedia donations model.

- Technological policy: Open source platform.

- Knowledge policy: Creative Commons license (CC BY) and data are open.

- Social responsibility: Most creators or producers use FreeSound to find sound sources.

\subsection{7. ХOBB}

The project, constituted as a cooperative, is the result of matching two research groups from different disciplines, sociology and technology, within Universitat Autonoma de Barcelona (UAB). After the rejection of the national blind association, ONCE, the promoters, with the support of other associations for the visually impaired, got resources from a Barcelona City Council grant to finance the first prototype in Creu Coberta Street. Beacons allow blind people to find information about establishments (e.g., products, offers, and open hours).

- Governance: Periodic assembly meeting.

- Economic model: Everybody could use it for free, but if somebody gets economic profit from the network they must pay for it.

- Technological policy: The project, based on a replicable open digital infrastructure, is just starting.

- Knowledge policy: Open data.

- Social responsibility: The main objective of the project is based on inclusion.

\subsection{8. eReuse}

Computers today are just recycled, not reused. eReuse develops open-data and open-source tools and services to reduce the costs of refurbishing and reusing computers. It was created in 2015 by Pangea, an independent non-profit association, with 15 community organizations. eReuse launched a tool to trace the origin of reused material and see if it is recycled at the end of its life.

- Governance: The decision-making process of participation focuses on local sovereignty and global federation.

- Economic model: The possibility of agreement with Abacus, in 2017, has allowed the project to get a new dimension by introducing machine cooperative to the recycling circuit. In that sense, there are good prospects for paid services growth (e.g., equipment redistribution, devices appraisal, or reporting information).

- Technological policy: Based on decentralized open-source software.

- Knowledge policy: Open data.

- Social responsibility: The project is based on reuse to decrease unnecessary production impact.

\subsubsection{Sentilo}

Sentilo is a platform to collect data from sensors. It was formed by the Barcelona City Council in 2012 in the framework of the Internet of Things. The proposal was based on the scenario of exponential sensors growth, when a space would be needed with structured information on each sensor system. Ten other cities, such as Terrassa, have subsequently implemented it. 
- Governance: The organization works as a foundation and the participation model is open.

- Economic model: Some of the proceedings are published on the website.

- Technological policy: FOSS (LGPL3).

- Knowledge policy: Open data.

- Social responsibility: One of the project's objectives is to avoid duplicate networks.

\subsubsection{Pam a Pam}

The platform, born in 2012, is a project by Setem and XES (two organizations linked to SSE) to promote responsible consumption. A community of volunteers maps the initiatives through a qualitative questionnaire. Currently, the project is in a renewal phase with a revitalization plan to face the difficulty of maintaining territorial community mobilization. At the same time, the promoters want to get a self-managed sustainability funding model, apart from subsidies, and legal independence from Setem.

- Governance: Periodic members' assemblies and open participation.

- Economic model: A grant from Barcelona City Council, proposed by Setem, allowed the initial founding. In 2014, a European grant permitted the incorporation of territorial facilitators and launched a new website that was more systematic and elaborate.

- Technological policy: FOSS.

- Knowledge policy: Open data on demand. The new website will allow it to be downloaded.

- Social responsibility: The whole project is linked to the social and solidarity economy.

\subsection{Curve of Growth and Evolutionary Stages of the Cases}

The curve of growth shown in Figure 2 represents the stages of evolution and growth of an organization, with an initial kick-off, deep growth, maturation with stabilization, and the renewal or gradient phase. At the co-creation session, each of the 10 cases positioned themselves on the curve. The cases positioned themselves in various stages on this curve of growth. The majority of them, however, located themselves in a positive stage of their activity.

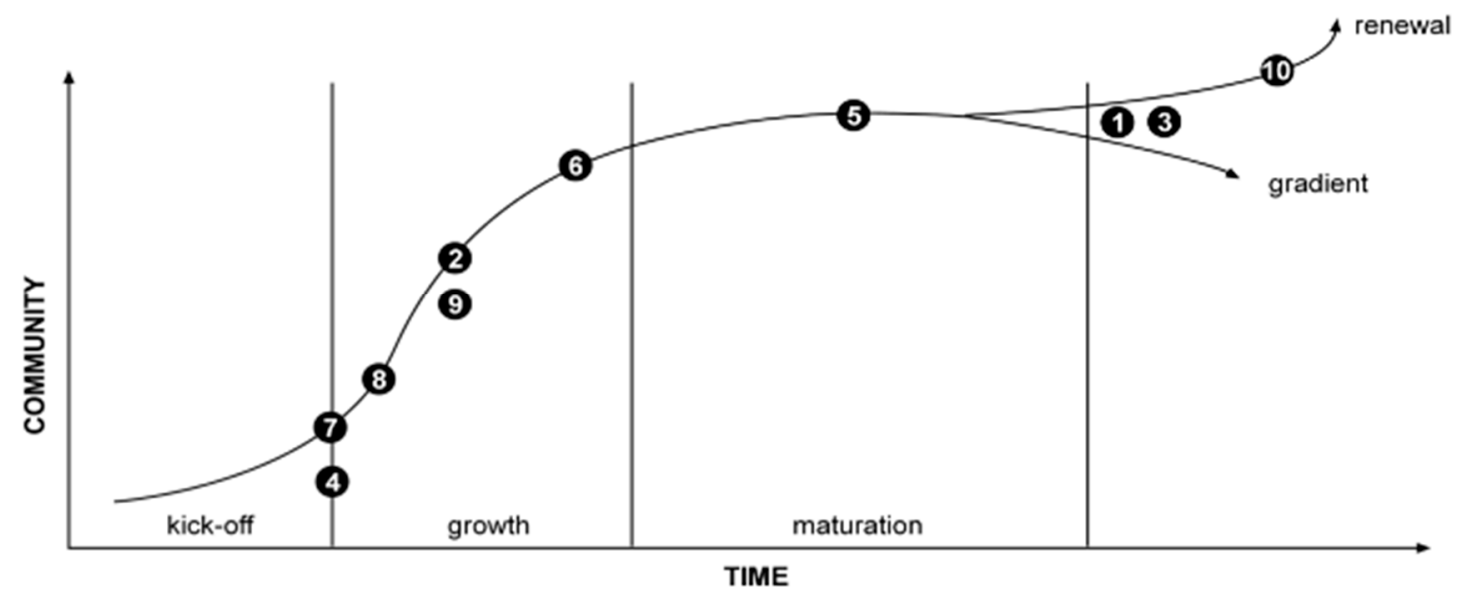

Figure 2. Summary of project stage evolution: (1) El Recetario; (2) SmartIB; (3) Goteo; (4) Katuma; (5) Bdtonline; (6) XOBB; (7) FreeSound; (8) eReuse; (9) Sentilo; (10) Pam a Pam.

\subsection{Case Comparison Analysis}

According to the results (Table 2: case comparison between the cases of the commons balance), none of the cases fulfill $100 \%$ of the five qualities. However, the majority of them accomplish aspects of the commons star collaborative economy review at a good level. Cases 3 (Goteo), 8 (eReuse), and 
especially 10 (Pam a Pam) achieve in a holistic approach achieving the majority of commons criteria. Two of these projects (Goteo and Pam a Pam) are in a post-maturation evolutionary stage. The qualities linked to the non-profit economic dimension and open participation in governance are the ones more cases fulfill, while technological decentralization, open data, and inclusion indicators (in these order) are the areas less fulfilled by the cases. The governance and economic model get the best evaluation, but open participation and non-profit organization have better valuation than cooperative governance and transparency, respectively. Overall, Case 2 (SmartIB), which is in the early platform development stage, has accomplished the fewest criteria.

Table 2. Case comparison between the cases of the commons balance. Green: fulfilment, Orange: Partial fulfilment; Red: unfulfillment. Cases: (1) El Recetario; (2) SmartIB; (3) Goteo; (4) Katuma; (5) Bdtonline; (6) XOBB; (7) FreeSound; (8) eReuse; (9) Sentilo; (10) Pam a Pam.

\begin{tabular}{|c|c|c|c|c|c|c|c|c|c|c|c|}
\hline Dimensions & Sub-Dimensions & 1 & 2 & 3 & 4 & 5 & 6 & 7 & 8 & 9 & 10 \\
\hline GOV & $\begin{array}{l}\text { Type of organization } \\
\text { Open participation }\end{array}$ & & & & & & & & & & \\
\hline $\mathrm{ECON}$ & $\begin{array}{c}\text { Goal } \\
\text { Transparency }\end{array}$ & & & & & & & & & & \\
\hline TECH & $\begin{array}{c}\text { FOSS } \\
\text { Decentralized }\end{array}$ & & & & & & & & & & \\
\hline KNOWL & $\begin{array}{c}\text { Copyleft } \\
\text { Open data }\end{array}$ & & & & & & & & & & \\
\hline SOC & $\begin{array}{l}\text { Inclusion } \\
\text { Green }\end{array}$ & & & & & & & & & & \\
\hline
\end{tabular}

\section{Discussion}

According to the application of the framework to the sample of 10 cases, we observe that there is no case which fulfills all of the dimensions, but several modalities of being pro-democratic as a digital platform.

Regarding business models, the majority of the 10 cases studied depart from a grant or public funding model and instead have a grassroots character. Four of the projects were connected to H2020 European funds. The main problem of this model is project maintenance when the economic support ends. Only one of the 10 cases mentioned here was awarded and used the services for entrepreneurship of Barcelona Activa, the Barcelona agency of development.

Regarding governance, several of the cases had the intention to get another legal constitution at the time of the study. The current legal formulas for economic association do not adapt well to commons collaborative economy activity. Several of these cases were provided by institutions, whether universities, such as FreeSound and eReuse with the UPF, or public administrations, as in the case of Sentilo being supported by the Barcelona City Council. Those that were legally constituted did so through an association (the simplest formula bureaucratically), a foundation, or a cooperative. In this sense, some associations (Bdtonline and Katuma, for example) manifested in the interviews the intention to become cooperatives. Others were already in the process of doing so (such as XOBB). We also observed other cases of collaborative economy platforms (such as femProcomuns) that were constituted as cooperatives but were not analyzed in this initial study. If the legal cooperative formula spreads among collaborative economy platform projects, as this investigation has found, we can expect new bonds in the growth of cooperatives [23] and the expansion of the social solidarity economy movement in the city of Barcelona [24].

Regarding technological policies, the majority of cases considered FOSS. At the same time, almost all of them centralized their architecture. In the same sense, with regard to knowledge policies, open licenses were more often extended than open data. 
Accomplishment of social responsibility criteria in the cases analyzed was not regular. Some cases were highly connected to environmental uses (such as eReuse or Katuma) while other favored social inclusion (such as XOBB). If we assess the 10 cases together, both subdimensions-green and inclusion—were half fulfilled.

Our analysis reflects another relevant issue to consider for future research into the ecosystem dimension of the cases. Collaborative economy has an important presence in Barcelona. More than 1000 cases have been identified as commons collaborative economies (see directori.p2pvalue.eu) [18]. The model is also very adaptable. A total of 33 areas of activity (with a broad range: culture, leisure, shopping, etc.) where the model is present in Barcelona have been identified [10]. Barcelona's collaborative economy has an important ecosystem dimension. This phenomenon links with the high number of social innovation practices that have a great tradition in the city [25] and shows the role of citizens in its transformation [26]. This is the case of the collaborative economy platform Katuma (one of the studied cases), for example, which is a potential tool to scale the activity of agroecology cooperatives that have been in Barcelona for over three decades [27].

The 10 cases analyzed showed different levels of connection with the Social and Solidarity Economy (SSE) and Digital Commons framework, network, and values. On the one hand, Goteo was the strongest project in the Digital Commons area. On the other hand, Pam a Pam was the most mature project with the SSE framework in terms of digital platform.

Despite the strong ecosystem, the majority of initiatives start but remain at initial stages, as a fabric of ideas and training, or kick off and grow to a certain level of satisfactory activity. Frequently, there is neither the expectation nor the intention to scale largely. The 10 cases in our sample positioned themselves at a developmental or mature position in the curve of growth, even if they were not considered "mainstream" or established with the big public. This is consistent with the results of the P2P Value investigation over a sample of 300, which pointed to a normal distribution of "success" (many medium cases), instead of a power law distribution with few very successful and the majority unsuccessful [28].

To sum up, our investigation shows that, beyond the controversial and unethical unicorn economy platforms, an alternative model of collaborative economy exists based on democratic qualities of procommon. The nature of these procommon alternatives is connected to the development of the platforms based on the principles of cooperativism. Nevertheless, the main challenge of these procommon collaborative economy projects is their scalability and sustainability.

Regarding future research, even if this study has allowed testing a framework to evaluate the qualities of sustainability and pro-democratization collaborative economy platforms, we consider it necessary to conduct a new investigation. It would, on the one hand, contemplate a broader sample of cases and, on the other hand, cosnider platform projects with different characterizations, from unicorn platforms to procommon platforms, passing through hybrid projects. This new research should provide a broader view of the key aspects of each of the approaches and the pathways of connection and learning between them.

Author Contributions: M.F.M. and R.E. contributed to the design and implementation of the research, to the analysis of the results and to the writing of the manuscript.

Funding: This research is part of the work carried out by the Dimmons research group in the framework of DECODE project (funded by the European Union's Horizon 2020 Programme, under grant agreement number 732546).

Conflicts of Interest: The authors declare no conflict of interest.

\section{References}

1. Fuster Morell, M. The unethics of sharing: Wikiwashing. Int. Rev. Inf. Ethics 2011, 15, 9-16.

2. Codagnone, C.; Biagi, F.; Abadie, F. The Passions and the Interests: Unpacking the 'Sharing Economy'; JRC Science for Policy Report; Institute for Prospective Technological Studies: IPTS, Seville, Spain, 2016. 
3. Fuster Morell, M.; Carballa Smichowski, B.; Smorto, G.; Espelt, R.; Imperatore, P.; Rebordosa, M.; Rocas, M.; Rodríguez, N.; Senabre, E.; Ciurcina, M. Multidisciplinary Framework on Commons Collaborative Economy; H2020-ICT-2016-1; DECODE: Barcelona, Spain, 2017.

4. European Commission. Communication from the Commission to the European Parliament, the Council, The European Economic and Social Committee and The Committee of the Regions; A European Agenda for the Collaborative Economy; 2.6.2016 COM(2016) 356 Final; European Commission: Brussels, Belgium, 2016.

5. Algar, R. Collaborative Consumption. Leis. Rep. 2007, 4, 16-17.

6. Botsman, R.; Rogers, R. What's Mine Is Yours: How Collaborative Consumption Is Changing the Way We Live; Harper Business: New York, NY, USA, 2010.

7. Cohen, B.; Kietzmann, J. Ride On! Mobility Business Models for the Sharing Economy. Organ. Environ. 2014, 27, 279. [CrossRef]

8. Heinrichs, H. Sharing economy: A potential new pathway to sustainability. GAIA 2013, 22, $228-231$. [CrossRef]

9. Palos-Sanchez, P.; Correia, M.B. O impacto da economia colaborativa medido através de termos de pesquisa na internet: Estudo de caso Blablacar. Rev. Tur. Desenvolv. 2018, 1, 1341-1354.

10. Fuster Morell, M. Cooperativismo de plataforma: Remover la economía colaborativa para un futuro sostenible. In Nexe.com, Quaderns d'Autogestió i Economia Cooperativa; Federació de Cooperatives de Treball de Catalunya: Barcelona, Spain, 2016.

11. Adigital. Los Modelos Colaborativos en Plataformas Digitales. 2017. Available online: https:/ /www.adigital. org/informes-estudios/los-modelos-colaborativos-demanda-plataformas-digitales / (accessed on 1 June 2017).

12. De Rivera, J.; López Gordo, Á.; Cassidy, P.; Apesteguía, A. A netnographic study of P2P collaborative consumption platforms' user interface and design. Environ. Innov. Soc. Transit. 2017, 23, 11-27. [CrossRef]

13. Finkel, L.; Gordo López, Á. Investigating Digital Social Networks: A Methodological Approach for Identifying Women Inclusion in Commercial Branding. In World Social Science Forum. Social Transformations and the Digital Age; International Social Science Council: Montreal, Canada, 2013.

14. Gordo, A.; De Rivera, J. The triple impact assessment of P2P collaborative consumption in Europe. In Research Report, with the Collaboration of María Avizanda (Desk Research E Delphi Study Research Assistant); Cibersomosaguas Universidad Complutense: Madrid, Spain, 2015.

15. Gordo López, A.; De Rivera, J.; Apesteguía, A. Facing the Challenge of Collaborative Consumption in Europe: A Time for Independent Metrics. In Proceedings of the Second International Workshop on the Sharing Economy (\#IWSE) @ESCP Europe, Paris Campus, Paris, France, 28-29 January 2016.

16. Hernández Bataller, B. Consumo Colaborativo o Participativo: Un Modelo de Sostenibilidad Para el Siglo XXI; Dictamen de Iniciativa, 21 January 2014; European Economic and Social Committee: Brussels, Belgium, 2014.

17. Scholz, T. Platform Cooperativism. Challenging the Corporate Sharing Economy; Rosa Luxemburg Stiftung: Berlin, Germany, 2016.

18. Fuster Morell, M.; Salcedo, J.; Berlinguer, M. Debate about the Concept of Value in Commons-Based Peer Production. In Proceedings of the International Conference on Internet Science (INSCI 2016), Florence, Italy, 12-14 September 2016. Lecture Notes in Computer Science Series (LNCS) 9934.

19. Bauwens, M. Cooperativismo Abierto Para la era del P2P. Guerrilla Translation. 3 July 2014. Available online: http:/ / www.guerrillatranslation.es/2014/07/03/cooperativismo-abierto-para-la-era-p2p/ (accessed on 1 April 2017).

20. Benkler, Y. The Wealth of Networks: How Social Production Transforms Markets and Freedom; Yale University Press: New Haven, CT, USA, 2006.

21. Espelt, R.; Peña-López, I.; Vega, N. Plataformas digitales: Grupos y cooperativas de consumo versus La Colmena que dice sí, el caso de Barcelona. In La Economía Colaborativa en la era Del Capitalismo Digital. Revista de Estudios para el Desarrollo Social de la Comunicación (Redes.com); Grupo Interdisciplinario de Estudios en Comunicación, Política y Cambio Social: Sevilla, Spain, 2017.

22. Tellis, W.M. Application of a case study methodology. Qual. Rep. 1997, 3, 1-19.

23. Roelants, B.; Hyungsik, E.; Terrasi, E. Cooperatives and Employment: A Global Report; CICOPA/Desjardin: Quebec City, QC, Canada, 2014.

24. Fernández, A.; Miró, I. L’Economia Social i Solidària a Barcelona; La ciutat invisible: Barcelona, Spain, 1997. 
25. Blanco, I.; Cruz, H.; Martínez, R. Barris Desafavorits Davant la Crisi: Segregació Urbana, Innovació Social $i$ Capacitat Cívica; Universitat Autònoma de Barcelona, Recercaixa: Bellaterra, Spain, 2015; Available online: https:/ / barrisicrisi.wordpress.com (accessed on 15 January 2018).

26. Nel·lo, O. La Ciudad en Movimiento: Crisis Social y Respuesta Ciudadana; Díaz\&Pons: Madrid, Spain, 2015.

27. Espelt, R.; Peña-López, I.; Losantos, P.; Rodríguez, E.; Martín, T.; Pons, F. Mapping agro-food consumption groups in the city of Barcelona. In Proceedings of the XXVI ESRS Congress, Aberdeen, Scotland, 18-21 August 2015; Kohe, M., Koutsouris, A., Larsen, R.B., Maye, D., Noe, E., Oedl-Wieser, T., Philip, L., Pospěch, P., Rasch, E.D., Rivera, M.J., et al., Eds.; The James Hutton Institute: Aberdeen, Scotland, 2015.

28. Fuster Morell, M. Towards a theory of value of platform cooperativism. In Ours to Hack and to Own. The Rise of Platform Cooperativism. A New Vision for the Future of Work and a Fairer Internet; Scholz, T., Schneider, N., Eds.; OR Books: New York, NY, USA, 2017; Available online: http:/ / www.orbooks.com/catalog/ours-to-hackand-to-own/ (accessed on 24 February 2018).

(C) 2018 by the authors. Licensee MDPI, Basel, Switzerland. This article is an open access article distributed under the terms and conditions of the Creative Commons Attribution (CC BY) license (http:/ / creativecommons.org/licenses/by/4.0/). 